\title{
Didactic Material Production Management
}

\author{
Andreza Regina Lopes da Silva, Andreia de Bem Machado, Fernando José Spanhol \\ Universidade Federal de Santa Catarina, Florianópolis, Brazil
}

\begin{abstract}
The preparation of didactic materials involves management and pedagogical practices that directly infer the quality of a course, as it is considered that the didactic material is the leitmotif of the teaching-learning process. The objective of this study is to map the production management practices and didactic content management for distance education (DE). The methodological procedure used for the gathering of practices adopted in the preparation of didactic materials followed the basic principles of exploratory research. Data collection technique was made though semi-structured interviews, seeking to identify best practices from benchmarking in institutions of Southern Brazil. For the analysis of collected data, we did qualitative descriptive analysis. The results showed that the majority of the surveyed institutions do not follow a management model for the production of didactic materials. It is expected that the mapping of good practices presented in this research can contribute to the debate on management in the process of production of didactic materials in DE from the perspective of a model of instructional design in which originates and intersects the production of didactic materials for the modality.
\end{abstract}

Keywords: distance education, didactic material, instructional design

\section{Introduction}

In the context of distance education (DE), the production of didactic materials is the determining factor of success in a course, because it assumes the role of guide in the teaching-learning process. The development of didactic materials involves the management of different actors, processes, and technologies, so that a course can be offered with quality and suite to the needs of the expected audience. As for the importance of improvement of production processes of didactic materials on DE, management practices can be considered a strategic point in the maintenance and continuity of the system.

Benchmarking, a management strategy created at the end of the 1970s in order to identify best practices within an organization, is an action that can be performed on educational projects to identify best practices and propose solutions based on new knowledge.

Batista (2012) and Balm (1995) indicated benchmarking as an internal and/or external practice to the institution in search of better references for comparison of processes, products, and services of the same or similar branch. For North and Rivas (2008), benchmarking basically let you compare the structuring processes and identify best practices in a company. For the Asian Productivity Organization (APO), benchmarking is a

\footnotetext{
Andreza Regina Lopes da Silva, Ph.D., student of the Graduate Program in Engineering and Knowledge Management, Universidade Federal de Santa Catarina.

Andreia de Bem Machado, Ph.D., student of the Graduate Program in Engineering and Knowledge Management, Universidade Federal de Santa Catarina.

Fernando José Spanhol, Ph.D., undergraduate professor of Information and Communication Technologies, Universidade Federal de Santa Catarina, Araranguá; professor of the Graduate Program in Engineering and Knowledge Management, Universidade Federal de Santa Catarina.
} 
process with the goal to find, adapt, and implement new practices based on existing models (APO, 2005). According to the APO, benchmarking begins with the identification of what you want to improve followed by learning about how to improve, through partnership and knowledge sharing of institutions that stand out in the area in question. Benchmarking plans to implement change, monitoring the performance and the identification of new opportunities for improvement (APO, 2005).

\section{Method}

To identify best practices in the production of didactic materials in DE using the benchmarking tool, this study adopted some steps of exploratory research, such as visits and semi-structured interviews. Instructional design became the object of study, because it is understood that it guides the management of development of didactic materials in DE.

After collecting information, the instructional design practices identified were organized, creating a dialogical problematizing array based on preset conceptual categories. To analyze the information collected, analysis of the Collective Subject Discourse (CSD) of Lefevre and Lefevre (2012) was used as reference. This procedure meets in a speech-synthesis the key expressions and the central idea.

Key expressions are pieces of excerpts or segments, continuous or discontinuous of speech, which must be selected by the researcher and that reveal the essence of the content of the statement or speech (Lefevre \& Lefevre, 2012, p. 73).

The central idea is a name or linguistic expression that reveals and describes the most synthetic and accurately as possible the meaning or the meaning of the key expressions. The central idea is what the interviewee meant (or what, about what) and the key expression as it was said (Lefevre \& Lefevre, 2012, pp. 76-77).

Initially, it was mapped, for the research, companies in the State of Santa Catarina that offer educational solutions, according to the Secretaria de Estado do Desenvolvimento Econômico Sustentável/Secretary of State for Sustainable Economic Development (SDS), published in 2013. It is understood as educational solutions, according to an interview with a representative of the SDS, innovation to facilitate the process of teaching and learning, which involves companies and projects that develop products related to information and communications technology (ICT). To refine the search, we selected the middle region of the greater Florianopolis/Santa Catarina, resulting in 67 institutions offering educational solutions. Of these, 20 companies are described in the report as having something to do with DE service and only 17 of them have a steady stream of demand for DE; the other three serve projects by specific demands sporadically. Of the 17 institutions mapped, after previous contact (email and telephone), only six were selected for interviews, because they work with the production of didactic materials, a specific focus of this study. The result was a sample, based on SDS (2013), of six institutions: four private companies providing service, a federal public educational institution, and a community education foundation.

To diversify the sample, we used the Census EaD. BR 2013 (Associação Brasileira de EaD/Brazilian Association of Distance Education [ABED], 2014), from which have been mapped intentionally institutions of Santa Catarina. Through contact held previously, considering the central objective of research (production of didactic materials), we sought to complete the initial sample in order to cover four segments for this research: (a) private institution (educational or service provider to DE); (b) public educational institution; (c) community education foundation; and (d) autarky. As a result, we had the participation of other three institutions: (a) a community foundation; (b) a public institution; and (c) an autarky. In addition to the nine institutions, we 
sought two more of private character to draw up different sample materials previously defined. One of the selected institutions focused on the production of materials for the training of clients who purchase their service (software). The other institution is part of an educational group considered leader in the sector of DE in Brazil.

Thus, the effective sample of this research consists of 11 organizations of different areas: six private institutions (five service providers and an educational institution), two public education institutions (federal and state), two community educational foundations, and an autarky.

\section{Results and Discussion}

The questions that guided the interviews for data collection were prepared in semi-structured mode and conducted openly in order to meet the peculiarities about the production process of didactic material. The interview included 21 questions organized into four areas: (a) identification (interviewed and institution); (b) demand and didactic model; (c) a multidisciplinary team; and (d) production process.

The answers were analysed based on key expressions and arranged in a problem matrix, using a data spreadsheet software, based on four axes defined, each with subsections determined by researchers in order to meet the objective of the research. After this segmentation, key expressions were identified and central ideas were defined by spheres. Table 1 presents the description of the sample of private institutions (education and DE services providers).

Table 1

Central Ideas of Private Institutions (Education and DE Services Providers)

\begin{tabular}{|c|c|c|}
\hline Area & Subsection & Central idea \\
\hline \multirow{2}{*}{ Identification } & Time of existence & $\begin{array}{l}\text { Between } 8 \text { and } 45 \text { years of presence on the market, with a concentration between } 8 \text { and } \\
20 \text { years }\end{array}$ \\
\hline & Time working with DE & $\begin{array}{l}\text { Between } 4 \text { and } 19 \text { years, generally (in four of the six institutions surveyed) commencing } \\
\text { after the implementation of the company }\end{array}$ \\
\hline \multirow[t]{4}{*}{$\begin{array}{l}\text { Demand and } \\
\text { didactic model }\end{array}$} & Demand & $\begin{array}{l}\text { Focused on the production of materials for another private institution (academic and } \\
\text { corporate material). Two companies use their own material. The demand is established } \\
\text { through partnerships, commercial sector contacts, and direct customer demand. Half of } \\
\text { the companies interviewed still participate in bidding. The production of didactic } \\
\text { materials, in large part, is originally from the menu of disciplines organized in Political } \\
\text { Course Project (PCP) planned by the institution; undergraduate, graduate, extension, } \\
\text { and technical course; and short-term training. In some situations, the material is drawn } \\
\text { from meetings for the routing of the briefing, which initiates the instructional design of } \\
\text { the course. }\end{array}$ \\
\hline & Didactic model & $\begin{array}{l}\text { Based, according to all the respondents, in digital material and in Virtual } \\
\text { Teaching-Learning Environment (VTLE). Five of the six companies interviewed also } \\
\text { work with video classes. The printed material is produced and distributed on a smaller } \\
\text { scale, due to costs. Games (listed as interactive activities) and material for tablet have } \\
\text { been tentatively developed (around 50\% of the respondents adopt such features). It is } \\
\text { also mentioned the use of HTML5 language for responsive material. }\end{array}$ \\
\hline & Professionals & $\begin{array}{l}\text { A team is composed of a content teacher; an instructional designer (ID); a proofreader; a } \\
\text { graphic designer (GD), or a Web designer or multimedia designer; and an environment } \\
\text { programmer. The coordination is organized by project in four of the companies } \\
\text { interviewed, organized by project and by area in one of the companies and organized by } \\
\text { people in one of the companies. In addition to these professionals, some institutions } \\
\text { have a staff video writer, monitor, tutor, educational analyst, information analyst, } \\
\text { plagiarism analyst, developer of learning objects, and illustrator. }\end{array}$ \\
\hline & & $\begin{array}{l}\text { Content teacher: Writes or organizes information for content-base. In some institutions } \\
\text { surveyed, this professional also elaborates the learning activities and evaluation, in } \\
\text { addition to the video classes. }\end{array}$ \\
\hline
\end{tabular}


(Table 1 to be continued)

\begin{tabular}{|c|c|c|}
\hline \multirow[t]{2}{*}{$\begin{array}{l}\text { Multidisciplinary } \\
\text { team }\end{array}$} & $\begin{array}{l}\text { Responsibilities of each } \\
\text { function }\end{array}$ & $\begin{array}{l}\text { ID: Operates in different scenarios, such as production, organisation, and adaptation of } \\
\text { content for educational purposes; travel planning; and management from concept to } \\
\text { final validation, as well as the monitoring of content, didactic language adaptation for } \\
\text { DE, instructional design validation, and production of content with the client. An ID } \\
\text { can also work with the production and organization of screens to the Web. } \\
\text { Proofreader: Responsible for spell check and textual and material regulations. } \\
\text { GD: Responsible for the visual identity of the project in different media. } \\
\text { Programmer: Prepares the VTLE, organizes the course, prepares the space for } \\
\text { exchange of material management, and trains for tool use. } \\
\text { Project coordination: Accompanies one or more projects from conception to } \\
\text { completion, applying knowledge and technique for its implementation, as well as } \\
\text { team's leadership and communication with senior management. } \\
\text { Coordination by project and by area: Accompanies the activities related to the area } \\
\text { under his/her responsibility. } \\
\text { Coordination by people: Accompanies the work to be performed by a team organized } \\
\text { in different areas. } \\
\text { Plagiarism analyst: Responsible for ensuring material's authenticity and avoiding } \\
\text { copyright infringement. } \\
\text { Illustrator: Responsible for illustration or animation. }\end{array}$ \\
\hline & $\begin{array}{l}\text { Technologies used by } \\
\text { each function }\end{array}$ & $\begin{array}{l}\text { Content teacher: Text editor, according to all the respondents. Some companies also } \\
\text { use a presentation editor. } \\
\text { ID and proofreader: Text editor in all companies, and presentation and PDF files } \\
\text { editor in some cases, in addition to authoring tool for specific activities. } \\
\text { GD: Adobe package for all respondents, as well as authoring tool in some cases. An } \\
\text { institution uses its own technology-"Inside Framework." } \\
\text { Programmer: Most of respondents work with the Modular Object-Oriented Dynamic } \\
\text { Learning Environment (Moodle) software. Some companies work with the client } \\
\text { platform and one institution has its own platform for hosting the course. } \\
\text { Coordination: Three of the six institutions interviewed have their own software. The } \\
\text { other companies use spreadsheet, some shared in drive. Two respondents, in addition } \\
\text { to their own software, also adopt a supporting software, such as Microsoft Project, } \\
\text { virtual Kanban, and practice of Project Management Body of Knowledge (PMBOK). } \\
\text { Shanel, Trello, and Redmine were also mentioned as management tools. }\end{array}$ \\
\hline \multirow{4}{*}{$\begin{array}{l}\text { Production } \\
\text { process }\end{array}$} & Processes mapping & $\begin{array}{l}\text { Four of the six companies surveyed have the material production process mapped and } \\
\text { visible to all. However, during the interviews, only one mapping was visible. Two } \\
\text { respondents indicated not having clear the mapping process, because the process is not } \\
\text { explicit, or because it is not aligned to the business unit. Three of the surveyed } \\
\text { companies review the process at the end of the project (for example, meeting of lesson } \\
\text { learned), two do the review throughout the process, and one does not review, follow } \\
\text { the flow of software. }\end{array}$ \\
\hline & Flow & $\begin{array}{l}\text { Three institutions consider that the production process begins with contact between } \\
\text { client and project manager for planning and opening of the project. The remaining } \\
\text { surveyed companies have the beginning of the project from the elaboration of content } \\
\text { (which can go for adjust by the ID or for approval by the professor, or for } \\
\text { proofreading). Some companies validate the contents at the first step; others at the end } \\
\text { of the validation process. The vast majority of the respondents do only one } \\
\text { proofreading to reduce production time. After that, the material is diagrammed and } \\
\text { validated by the ID, to later be adjusted by GD and then posted in the VTLE. }\end{array}$ \\
\hline & Deadline & $\begin{array}{l}\text { All companies interviewed set the deadline of the project according to the customer's } \\
\text { need; the development team needs to make it work. Four respondents indicated that } \\
\text { the deadline is met, and two companies said that generally (around } 50 \% \text { of projects) } \\
\text { do not meet the agreed time limit, although they are aware of the need. }\end{array}$ \\
\hline & Challenge & $\begin{array}{l}\text { For four of the six companies interviewed, the question people is the challenge-To } \\
\text { maintain, manage, and select qualified persons with competence in the area. People } \\
\text { are considered differential in the process, contributing to the continued improvement } \\
\text { of the production. The development process itself is mentioned as a challenge, which } \\
\text { requires flexibility and quality assurance. Another challenge is the lack of reference in } \\
\text { the market itself about how to do DE, what it is wanted, and how it is wanted. }\end{array}$ \\
\hline
\end{tabular}

Note. Source: Authors. 
Table 2 provides a description of the sample of public education institutions.

Table 2

Central Ideas of Public Educational Institutions

\begin{tabular}{|c|c|c|}
\hline Area & Subsection & Central idea \\
\hline \multirow{2}{*}{ Identification } & Time of existence & Average of 50 years \\
\hline & Time working with DE & Between 7 and 9 years \\
\hline \multirow{2}{*}{$\begin{array}{l}\text { Demand and } \\
\text { didactic model }\end{array}$} & Demand & $\begin{array}{l}\text { Production for own use, focusing on graduation, eventually postgraduate } \\
\text { (specialization) and extension. The material is elaborated from the educational } \\
\text { project. }\end{array}$ \\
\hline & Didactic model & $\begin{array}{l}\text { Printed and digital materials, as well as VTLE. One of the companies } \\
\text { interviewed prepares Web lessons and learning objects to promote interaction. } \\
\text { Another company with the same concern works with thematic DVD. }\end{array}$ \\
\hline \multirow{3}{*}{$\begin{array}{l}\text { Multidisciplinary } \\
\text { team }\end{array}$} & Professionals & $\begin{array}{l}\text { The content teacher works on demand. The ID and proofreader are scholars of } \\
\text { the Universidade Aberta do Brasil (UAB) and outsourced. As for the GD and } \\
\text { the illustrator, one researched institution has an information technology (IT) } \\
\text { system, which these professionals are part of; in another institution, they } \\
\text { integrate, along with the programmer, the core of Graphic Design of } \\
\text { Hypermedia (GDH) and are responsible for the visual design, the illustration, } \\
\text { and the treatment of VTLE. Coordination is by project. One of the interviewed } \\
\text { institutions also has external referee and editorial committee, activities with } \\
\text { content analysis function. }\end{array}$ \\
\hline & $\begin{array}{l}\text { Responsibilities of each } \\
\text { function }\end{array}$ & $\begin{array}{l}\text { Content teacher: Responsible for preparing the content and generally monitoring } \\
\text { of discipline. } \\
\text { ID: Responsible for contact with the teacher, the project presentation and DE } \\
\text { learning methodology, language adaptation, for diversifying ways of } \\
\text { representing knowledge, the proposal of activities, and for planning of } \\
\text { educational discipline and pedagogical sketchbook. } \\
\text { Proofreader: Responsible for reviewing spelling and regulatory review. } \\
\text { GD: Responsible for developing graphics, Web classes, and other elements that } \\
\text { have didactic contribution. } \\
\text { One institution has a GDH core that diagrams printed, digital material, and } \\
\text { virtual environment designer customizes the VTLE. One company has a video } \\
\text { writer and an illustrator. Coordination is by project. One of the respondents also } \\
\text { has the coordination of production, responsible for the production, regardless of } \\
\text { the project. }\end{array}$ \\
\hline & $\begin{array}{l}\text { Technologies used by } \\
\text { each function }\end{array}$ & $\begin{array}{l}\text { Teacher, ID, and proofreader: Text editor. An institution interviewed has an ad } \\
\text { hoc proofreader, which works with PDF file. } \\
\text { Editorial committee and screenwriter: Text editor. } \\
\text { GD and illustrator: Adobe. } \\
\text { Programmer: Moodle. } \\
\text { Coordination: Spreadsheet. }\end{array}$ \\
\hline \multirow{4}{*}{ Production process } & Mapping processes & $\begin{array}{l}\text { In both surveyed institutions, the mapping exists and is visible to all, online and } \\
\text { printed; a respondent presents the flow on a banner. One institution reviews the } \\
\text { mapping over every production process; the other does not. }\end{array}$ \\
\hline & Flow & $\begin{array}{l}\text { The teacher prepares the content. In one of the institutions, the content is still } \\
\text { evaluated by the editorial committee or referee. Then, ID is made, and then goes } \\
\text { through the approval of the teacher. Later happens the content review followed } \\
\text { by diagramming. Then, it is approved by the teacher and the ID. The GD makes } \\
\text { necessary adjustments and the material is forwarded to the printer and to VTLE. }\end{array}$ \\
\hline & Deadline & $\begin{array}{l}\text { The period considered is of the graphics. On the team, the deadline is flexible, } \\
\text { i.e., it is hardly fulfilled-A characteristic of intensive processes in intellectual } \\
\text { production. }\end{array}$ \\
\hline & Challenge & $\begin{array}{l}\text { The challenge is the management of people, especially sharing of work. Another } \\
\text { challenging factor is the lack of institutionalization of DE. }\end{array}$ \\
\hline
\end{tabular}

Note. Source: Authors. 
Table 3 shows the sample of community education foundations.

Table 3

Central Ideas of Educational Foundations

\begin{tabular}{|c|c|c|}
\hline Area & Subsection & Central idea \\
\hline \multirow{2}{*}{ Identification } & Time of existence & Consolidated institutions, with an average of 50 years \\
\hline & Time working with DE & Between 6 and 11 years \\
\hline \multirow[b]{2}{*}{$\begin{array}{l}\text { Demand and } \\
\text { didactic model }\end{array}$} & Demand & $\begin{array}{l}\text { Production for own use, focusing on undergraduate and postgraduate. One } \\
\text { foundation interviewed also has demand for extension courses and sequential } \\
\text { programs. Work based on PPC. }\end{array}$ \\
\hline & Didactic model & $\begin{array}{l}\text { Both surveyed institutions work with digital material and VTLE. One still } \\
\text { adopts printed materials and for tablet, interactive objects, and Web class, } \\
\text { seeking to meet the training through an array of competence. Another } \\
\text { foundation adopts video classes, in addition to digital material and VTLE. }\end{array}$ \\
\hline \multirow{3}{*}{$\begin{array}{l}\text { Multidisciplinary } \\
\text { team }\end{array}$} & Professionals & $\begin{array}{l}\text { The content teacher is hired by project demand. One foundation has reduced } \\
\text { team: The ID does the textual review as well as coordinating the production } \\
\text { and the GD runs the VTLE and does illustrations. One institution interviewed } \\
\text { has a video writer. Another has a diverse team, with ID, proofreader, GD, } \\
\text { illustrator, programmer, and coordinator of the production process. There are } \\
\text { also academic assistant, multimedia team, and learning evaluation team. }\end{array}$ \\
\hline & $\begin{array}{l}\text { Responsibilities of each } \\
\text { function }\end{array}$ & $\begin{array}{l}\text { Content teacher: Elaborates the content of discipline and learning activities. } \\
\text { ID: Acts in pedagogical management of content and in planning the course as } \\
\text { a whole. } \\
\text { Proofreader: Does the spell check and textual and regulatory review. } \\
\text { GD and illustrator: Diagram the material in printed and digital format, in } \\
\text { addition to working the visual identity of the project. } \\
\text { Programmer: Programmes the VTLE. } \\
\text { In both surveyed foundations, coordination acts in the production, including } \\
\text { the management of processes and people involved in the production of the } \\
\text { material. One of the institutions has an academic assistant to review the VTLE } \\
\text { material, so there is no need for the interference of the ID; Multimedia team to } \\
\text { work the learning object in Flash; and learning evaluation team for organizing } \\
\text { the bank of questions. }\end{array}$ \\
\hline & $\begin{array}{l}\text { Technologies used by each } \\
\text { function }\end{array}$ & $\begin{array}{l}\text { Content teacher, ID, and proofreader: Text editor. In one of the interviewed } \\
\text { institutions, in addition to the text editor, authoring tool is also used in some } \\
\text { situations. } \\
\text { GD and illustrator: Adobe and authoring tool. } \\
\text { VTLE programmer: Moodle. } \\
\text { Coordination: Text editor and spreadsheet editor. }\end{array}$ \\
\hline \multirow{4}{*}{$\begin{array}{l}\text { Production } \\
\text { process }\end{array}$} & Mapping processes & $\begin{array}{l}\text { In one of the foundations, the mapping is done digitally, in a repository, and } \\
\text { meetings are held to review it throughout the development of the project, if } \\
\text { necessary. The other institution has no mapping, because it considers that it is } \\
\text { implicit in people's minds, there is no need for review. }\end{array}$ \\
\hline & Flow & $\begin{array}{l}\text { The process begins with ID and the coordination, with the project planning. } \\
\text { After the teacher delivers the content, the instructional design of the material } \\
\text { is made, which is then reviewed. The ID validates the material and passes to } \\
\text { the GD to diagram; Subsequently, the ID and content teacher validate. The } \\
\text { project is transferred to the GD for adjustments, generating the final file to the } \\
\text { printer, in one of the institutions, and for the VTLE, in another. }\end{array}$ \\
\hline & Deadline & $\begin{array}{l}\text { Begins to count from the start date of the course and is not always fulfilled. } \\
\text { One of the institutions is able to meet the deadline, because it posts on VTLE } \\
\text { each unit of material, thus, not having printed material. }\end{array}$ \\
\hline & Challenge & $\begin{array}{l}\text { The challenge is diverse: Relating to people, the lack of pedagogical } \\
\text { assistance for DE, and the complexity of control of material production. }\end{array}$ \\
\hline
\end{tabular}

Note. Source: Authors.

Table 4 presents a sample of an autarky in the field of teaching continuing education and youth and adult education (YAE). 
Table 4

Central Ideas of Autarky

\begin{tabular}{|c|c|c|}
\hline Area & Subsection & Central idea \\
\hline \multirow{2}{*}{ Identification } & Time of existence & Sixty-three years in the market \\
\hline & Time working with DE & About 15 years \\
\hline \multirow{2}{*}{$\begin{array}{l}\text { Demand and } \\
\text { didactic model }\end{array}$} & Demand & $\begin{array}{l}\text { Production for public and private institutions-Industry, with demand for continuing } \\
\text { education and YAE. The client is the one looking for the autarky. The design of the } \\
\text { course starts from the demand. }\end{array}$ \\
\hline & Didactic model & $\begin{array}{l}\text { Printed and digital material, video classes, VTLE, and games based on a competence } \\
\text { array. }\end{array}$ \\
\hline \multirow{3}{*}{$\begin{array}{l}\text { Multidisciplinary } \\
\text { team }\end{array}$} & Professionals & Content teacher, ID, proofreader, GD, illustrator, IT staff, and coordinator by area. \\
\hline & \begin{tabular}{|l|} 
Responsibilities of each \\
function
\end{tabular} & $\begin{array}{l}\text { Content teacher: Organizes the content and training of those who will teach the course. } \\
\text { ID: Organizes the content, taking care of the proper language for DE and the amount } \\
\text { of page/hour, plus identify if the competencies proposed in the course will be } \\
\text { accomplished. } \\
\text { Proofreader: Performs textual and regulatory review. } \\
\text { Illustrator: Develops the illustrations of the material. } \\
\text { GD: Does the layout of the material. } \\
\text { IT team: Responsible for the VTLE. } \\
\text { Coordinator: Monitors the production process by project. }\end{array}$ \\
\hline & $\begin{array}{l}\text { Technologies used by } \\
\text { each function }\end{array}$ & $\begin{array}{l}\text { Content teacher, ID, and proofreader: Text editor. } \\
\text { GD and illustrator: Adobe. } \\
\text { IT team: Moodle. } \\
\text { Production coordinator: Spreadsheet editor. }\end{array}$ \\
\hline \multirow{4}{*}{$\begin{array}{l}\text { Production } \\
\text { process }\end{array}$} & Mapping processes & Available on the intranet. Revised along the way and adjusted when necessary. \\
\hline & Flow & $\begin{array}{l}\text { Starts with the industry's demand, which counts with coordination and ID to do the } \\
\text { planning. Then begins the preparation of the menu by the teacher. With the menu } \\
\text { approved, the organization of the content is made. This is adjusted by the ID and then } \\
\text { for proofreading, producing the material for diagramming. After being diagrammed, } \\
\text { the material goes back for the teacher's analysis and the ID's second textual revision. } \\
\text { The adjustments are made by the GD. The file is included in the VTLE and forwarded } \\
\text { to the printer. }\end{array}$ \\
\hline & Deadline & $\begin{array}{l}\text { It is usually served. This is attributed to the time spent on planning, which allows to } \\
\text { gain in production. }\end{array}$ \\
\hline & Challenge & Selection of trained personnel for DE flow. \\
\hline
\end{tabular}

Note. Source: Authors.

One can see that the process of production of teaching materials for DE, although relevant in the educational context, is not treated as a priority in Brazil in projects without practice and recognized process. Each institution presents its model and manages according to the needs of their clients. The results show the absence of a management model to plan, organize, coordinate, monitor, and control the process of production of teaching materials in DE projects. Such a process has unique features, different with each new project.

\section{Final Considerations}

This analysis took a sampling of Brazilian institutions of different spheres to have a comprehensive overview about the process of producing teaching materials for DE. In this research, one can see the need for more effective organization of production of didactic materials from the perspective of a model of instructional design, process in which originates and intersects the production of didactic materials for the modality.

This study predates a more detailed research, from the first author, which aims to elaborate a management model for the essential processes of the production of didactic materials for DE. 


\section{References}

Asian Productivity Organization (APO). (2005). Benchmarking training manual. Tokyo: APO. Retrieved January 11, 2015, from http://goo.gl/j5BD9X

Associação Brasileira de EaD/Brazilian Association of Distance Education (ABED). (2014). Censo EaD. BR 2013: Analytical report of distance learning in Brazil. Curitiba: Ibpex.

Balm, G. J. (1995). Benchmarking: A guide for the professional to become and remain the best of the best. Rio de Janeiro: Qualitymark.

Batista, F. F. (2012). Knowledge management model for the Brazilian public administration: How to implement knowledge management to produce results for the benefit of the citizen. Brasilia: IPEA.

Lefevre, F., \& Lefevre, A. M. C. (2012). Research of social representation: A quantitative/qualitative approach: The methodology of the collective subject discourse (2nd ed.). Brasília: Liber Livro.

North, K., \& Rivas, R. (2008). Gestión del conocimiento: Una guía práctica hacia la empresa inteligente (Knowledge management: A practical guide to intelligent enterprise). Buenos Aires: Libros en Red.

Secretaria de Estado do Desenvolvimento Econômico Sustentável/Secretary of State for Sustainable Economic Development (SDS). (2013). Mapping of educational solutions companies in the State of Santa Catarina. Florianopolis: Fundação CERTI. 